\title{
A Novel Marker Affecting Survival in Acute Non-variceal Upper Gastrointestinal Bleeding: Cardiac Troponin I
}

\section{Akut Varis Dışı Üst Gastrointestinal Kanamada Sağkalımı Etkileyen Yeni Bir Belirteç: Kardiyak Troponin I}

\author{
(1) Ramazan Dertli1, (1) Murat Bıyık1, (1) Ramazan Yolacan22, (1) Muharrem Keskin1, (1) Ahmet Karakarcayıldız²,

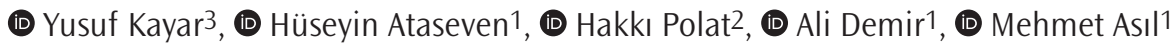

1Necmettin Erbakan University, Meram Faculty of Medicine, Department of Internal Medicine, Division of Gastroenterology, Konya, Turkey
2Necmettin Erbakan University, Meram Faculty of Medicine, Department of Gastroenterology, Konya, Turkey
3University of Health Sciences Turkey, Van Training and Research Hospital, Clinic of Internal Medicine, Division of Gastroenterology, Van, Turkey

\begin{abstract}
Introduction: Acute non-variceal upper gastrointestinal bleeding (ANVUGIB) is an important public health problem with high rates of morbidity and mortality. ANVUGIB results in hypovolemia, hypotension, and shock, increasing cardiac oxygen use and may cause elevated serum levels of cardiac troponin (cTn). In this study, we aimed to evaluate whether elevated cTnI has clinical significance in patients with ANVUGIB.

Methods: A total of 62 patients diagnosed with ANVUGIB whose serum cTnl levels were studied at the time of admission and follow-up in our clinic from January 2015 to January 2016 were included in the study. Patients with acute cardiac diseases that may cause elevated cTn were excluded from the study.
\end{abstract}

Results: Forty-three of the patients were male (69.4\%), and the mean age of all patients was $71.52 \pm 13.30$ years. The mean cTnl level was $0.042 \pm 0.097$ in all patients, with cTnl levels higher than the reference value in nine (14.5\%) patients. In logistic regression analysis, the factors found to contribute to cTnl were tachycardia, chronic kidney disease, and coronary artery disease. In receiver operating characteristic analysis, cutoff values of 0.025 and 6.5 were found for $\mathrm{CTnl}$ and the Rockall score, respectively. In addition, cTnl and the Rockall score were shown to affect survival [log-rank (Mantel-Cox) test: $p=0.011$; log-rank (Mantel-Cox) test: $p=0.014$; respectively].

Conclusion: We believe that serum cTnl levels studied during the first admission will be found useful as a biomarker in addition to the other existing risk determination systems, in order to identify patients at risk, even if findings of acute coronary syndrome are not observed in patients presenting with ANVUGIB.

Keywords: cTnl, upper gastrointestinal bleeding, rockall score

\section{ÖZ}

Amaç: Akut varis dıșı üst gastrointestinal sistem kanaması (AVDÜGSK) yüksek mortalite ve morbiditeye sahip önemli bir sağlık sorunudur. AVDÜGSK'leri hipovolemi, hipotansiyon ve şok tablosu oluşturarak kardiyak oksijen kullanımını artırır ve serum kardiyak troponin (kTn) düzeyinin yükselmesine neden olabilir. Biz bu çalıșmada AVDÜGSK'si olan hastalarda kTnı yüksekliğinin klinik bir öneme sahip olup olmadığını değerlendirmeyi planladık.

Yöntemler: Kliniğimize Ocak 2015-Ocak 2016 tarihleri arasında başvuran, AVDÜGSK tanısı konan, başvuru anında serum kTnl bakılmış olan 62 hasta çalışmaya dahil edildi. kTn yüksekliğine sebep olabilecek akut kardiyak hadisesi olan tüm hastalar çalışma dışı bırakıldı.

Bulgular: Çalıșmaya alınan hastaların 43'ü erkek $(\% 69,4)$

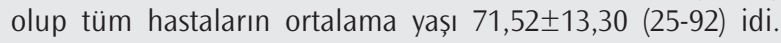
Tüm hastaların ortalama kTnl düzeyi $0,042 \pm 0,097$ olup 9 $(\% 14,5)$ hastanın kTnı düzeyi referans aralığının üzerinde idi. Yapılan lojistik regresyon analizinde kTnl düzeyi yüksekliğine katkı yapan faktörler taşikardi, kronik böbrek yetmezliği ve koroner arter hastalığı idi. Yapılan alıcı işletim karakteristiği analizinde $k T n l$ ve rockall skoru için eşik değeri sırasıyla; 0,025 ve 6,5 olarak saptandı ve kTnl ile rockall skorunun yükseliğinin sağkalım üzerinde etkili olduğu gösterildi [sırasıyla; logrank (Mantel-Cox) testi: $p=0,011$, log-rank (Mantel-Cox) testi: $\mathrm{p}=0,014]$.

Sonuç: AVDÜGSK ile başvuran hastalarda akut koroner sendrom bulguları olmasa bile ilk başvuruda serum kTnl düzeyinin bakılmasının riskli hastaların belirlenmesi açısından mevcut diğer risk belirleme yöntem ve skorlama sistemleriyle birlikte, bir biyobelirteç olarak kullanım alanı bulabileceği kanaatindeyiz.

Anahtar Kelimeler: kTnI, üst gastrointestinal sistem kanaması, Rockall skoru
Address for Correspondence/Yazıșma Adresi: Ramazan Dertli MD, Necmettin Erbakan University, Meram Faculty of Medicine, Department of Internal Medicine, Division of Gastroenterology, Konya, Turkey

Phone: +90 5072347539 E-mail: dededoc@hotmail.com ORCID ID: orcid.org/0000-0002-6205-8983

Cite this article as/Atıf: Dertli R, Bıyık M, Yolacan R, Keskin M, Karakarcayıldız A, Kayar Y, Ataseven H, Polat H, Demir A, Asıl M. A Novel Marker Affecting Survival in Acute Non-variceal Upper Gastrointestinal Bleeding: Cardiac Troponin I. İstanbul Med J 2021; 22(1): 38-44.

(C) Copyright 2021 by the University of Health Sciences Turkey, Istanbul Training and Research Hospital/Istanbul Medical Journal published by Galenos Publishing House

(C) Telif Hakkı 2021 Sağıı Bilimleri Üniversitesi Istanbul Ĕgitim ve Araştırma Hastanesi/Istanbul Tıp Dergisi, Galenos Yayınevi tarafından basılmıștır.
Received/Geliș Tarihi: 11.05 .2020 Accepted/Kabul Tarihi: 25.12.2020 


\section{Introduction}

Acute non-variceal upper gastrointestinal bleeding (ANVUGIB) is an important health problem with high rates of morbidity and mortality (1). Mortality from ANVUGIB reaches up to $40 \%$, especially in patients who develop hemodynamic instability. Therefore, by detecting and treating the locale and cause of bleeding in the early period, hemodynamic stabilization is ensured and has vital importance (2).

Cardiac troponin I (cTnl) is an invaluable cardiac marker with high sensitivity and specificity in the diagnosis of myocardial necrosis and the classification of cardiac risk (3). cTnl plays an important role together with $\mathrm{CTnC}$ and $\mathrm{cTnT}$ in the regulation of cardiac muscle contraction. cTnl is not found in skeletal muscle and has high sensitivity, even under conditions causing severe muscle damage, such as severe muscle trauma, surgery, muscle diseases, and comprehensive exercise (4). Although elevation of cTn is a marker of myocardial necrosis, its level may also be increased in diseases that cause no myocardial damage, such as sepsis, pulmonary embolism, heart failure, and renal failure (5). Elevated cTnl has an important role in the diagnosis, treatment, and follow-up of acute coronary syndrome when evaluated together with the presence of risk factors and the clinical picture. There are studies reporting that serum cTnl levels elevated due to noncardiac causes may be associated with a poor prognosis in these diseases (6-8).

ANVUGIB may lead to hypovolemia, hypotension, and septic shock picture, increase cardiac oxygen use, and cause elevation of serum cTn levels (9). Among the other diseases causing an increase in serum cTn levels through a similar mechanism are sepsis, septic shock, systemic inflammatory response syndrome, and emergency noncardiac critical conditions $(6,10,11)$. There are studies in the literature evaluating the association of ANVUGIB and myocardial infarction (12). Considering that cTnl may also be elevated in various noncardiac diseases, in the present study, we aimed to investigate serum cTnl levels in patients with ANVUGIB in whom acute myocardial pathologies were ruled out and whether elevated cTn1 has clinical significance.

\section{Methods}

A total of 62 patients who presented to our university gastroenterology and emergency department between January 2015 and January 2016, were diagnosed with ANVUGIB, whose serum cTnI were examined at the time of admission, and in whom the concomitant presence of acute coronary syndrome was ruled out with necessary investigations were included in this study. The study was approved by Necmettin Erbakan University, Meram Faculty of Medicine Ethics Committee (approval number: 2017/811, date: 24.02.2017). All participants provided written consent for participation in the study. Patients with stable coronary artery disease (CAD), hypertension controlled with drugs, or chronic kidney disease (CKD) in addition to ANVUGIB were included in the study; patients with acute myocardial infarction, arrhythmias, heart failure, aortic dissection, valvular heart disease, cardiac contusion or hypertensive crisis, those with pulmonary embolism or severe pulmonary diseases, patients with myocarditis or pericarditis, those with acute cerebrovascular events determined, patients with infiltrative diseases such as hemochromatosis or amyloidosis, those with rhabdomyolysis due to any cause, patients with sepsis or septic shock, those with a severe burn above 30\%, cancer patients, those with cardiac arrest, and patients who underwent resuscitation and electrical cardioversion were excluded from the study.

Admission data on the patients included in the study were obtained by retrospective screening of the medical records that were prospectively recorded in the database and automation-recording program of our hospital. The records were examined, and patients' admission data including demographic features (age, gender etc), hemodynamic findings (blood pressure, pulse), administered drugs (antithrombotic, anticoagulant, and nonsteroidal anti-inflammatory drugs), laboratory data [serum $\mathrm{CTnI}$, hemoglobin $(\mathrm{Hb})$, leukocyte count, creatinine, urea, other laboratory investigations], and comorbidities (CKD, CAD etc) were recorded. The types and numbers of blood products transfused were determined for patients who received blood product transfusion during hospitalization in intensive care units (ICU) or wards.

The patients were divided into two groups according to cTnl values. Accordingly, patients with a serum cTnl value within the normal range (cTnl: 0.00-0.06 mg/L) were classified as group A, and those with a serum cTnl value, which was so high as to require clinical follow-up (cTnl $\geq 0.06$ $\mathrm{mg} / \mathrm{L}$ ) as group B. Patients with an admission systolic blood pressure $<90 \mathrm{mmHg}$ were considered as hypotensive, and those with a peripheral pulse rate $>90$ as tachycardic. The Glasgow-Blatchford score (13) and the Rockall score (14), determined by evaluating endoscopy reports, were calculated for each patient. The lesions detected on endoscopy were grouped according to the Forrest classification (15). The 30-day mortality rate was calculated. We allocated the surviving patients to group 1 and the patients who died to group 2.

\section{Statistical Analysis}

Statistical analysis was performed using the "IBM SPSS Statistics for Windows, Version 19.0" (Armonk, NY, IBM Corp.) software package. Continuous variables were expressed as mean \pm standard deviation, and categorical data as frequency and percentage (n, \%). The normality of continuous variables was tested with the Kolmogorov-Smirnov method. In the comparison of two groups, an Independent-Samples t-test was used for normally distributed variables and a Mann-Whitney $\mathrm{U}$ test for non-normally distributed variables. In order to determine the linear correlation between variables, Pearson's correlation test was used for the parametric variables and Spearman's correlation test for non-parametric variables. A logistic regression model was used to investigate whether various variables are independent risk factors for elevation of cTnI. In the multivariate analysis, independent effects of the possible risk factors in the prediction of survival were examined with the backward elimination method using Cox-regression analysis. In order to analyze survival, the cutoff value for cTnl was determined using receiver operating characteristic (ROC) curves. The effect of cTnl levels on survival was analyzed with a log-rank (Mantel-Cox) test. Survival rates were calculated with the Kaplan-Meier method. Differences were considered statistically significant at $p<0.05$.

\section{Results}

A total of 62 patients who presented due to ANVUGIB between January 2015 and January 2016 were included in the study. Of all patients, 43 (69.4\%) were male, and their mean age was $71.52 \pm 13.30$ years. 
All patients underwent endoscopy within the first 12 hours after presentation. When endoscopy results were evaluated, bleeding was found to originate from a duodenal ulcer in 27 (43.5\%), gastric ulcer in 19 (30.6\%), Mallory-Weiss lesions in 6 (9.7\%), and non-variceal various esophageal lesions in 10 (16.2\%) patients. When endoscopic findings of the patients with bleeding due to duodenal ulcer were examined, Forrest $1 \mathrm{~b}$ ulcer was found in 1 (3.7\%) patient, Forrest 2a in 7 (25.9\%) patients, Forrest 2b in 1 (3.7\%) patient, Forrest 2c in 10 (37\%) patients, and Forrest 3 ulcer in 8 (29.6\%) patients. When endoscopic findings of the patients with bleeding due to gastric ulcer were examined, Forrest $1 \mathrm{~b}$ ulcer was found in two (10.5\%) patients, Forrest 2a in five (26.3\%) patients, Forrest 2b in one (5.3\%) patient, Forrest 2c in three (15.8\%) patients and Forrest 3 in eight (42.1\%) patients.

Of all patients, 13 (21\%) were using anti-thrombotics, 12 (19.4\%) anticoagulants, 4 (6.5\%) both antithrombotic and anticoagulant drugs, 4 (6.5\%) nonsteroidal anti-inflammatory drugs, 2 (3.2\%) both nonsteroidal anti-inflammatory and anti-thrombotic drugs, and one (1.6\%) anti-coagulant, anti-thrombotic, and non-steroidal anti-inflammatory, while 26 (41.9\%) were not using any anti-coagulant, anti-thrombotic, or non-steroidal anti-inflammatory drug.

Serum cTnl levels were above the reference range in 9 (14.5\%) of the 62 patients, and the mean serum $\mathrm{CTnl}$ level was $0.042 \pm 0.097 \mathrm{mg} / \mathrm{L}$ in all patients. There were 53 patients in group $\mathrm{A}(85.5 \%)$ and 9 patients in group $B(14.5 \%)$. The mean serum cTnl level was found to be $0.017 \pm 0.015 \mathrm{mg} / \mathrm{L}$ in group $A$ and $0.19 \pm 0.20 \mathrm{mg} / \mathrm{L}$ in group $\mathrm{B}$, and the difference between the two groups was statistically significant $(p<0.001)$. The mean age was found to be $70.15 \pm 13.70$ years in group $A$ and $79.60 \pm 6.0$ years in group $B$, and the difference was statistically significant $(p=0.04)$. The mean $\mathrm{Hb}$ level was found to be $8.6 \pm 2.7 \mathrm{~g} / \mathrm{dL}$ in group $\mathrm{A}$ and $7.3 \pm 2.9 \mathrm{~g} / \mathrm{dL}$ in group $B$, and the difference was not statistically significant $(p=0.072)$. Demographic and laboratory data on the patients in groups $A$ and $B$ are given in Table 1.

When the patients in group A and group B were compared in terms of the need for blood transfusion, a mean of $4.74 \pm 4.6$ units of erythrocyte suspension was transfused in the patients in group A during hospitalization, while this amount was $7.44 \pm 7.7$ units in the patients in group B. The difference between the groups was not statistically significant $(p=0.350)$. The mean serum creatinine levels were $1.12 \pm 0.55$ $\mathrm{mg} / \mathrm{dL}$ and $1.69 \pm 0.68 \mathrm{mg} / \mathrm{dL}$ in the patients in group $\mathrm{A}$ and group $\mathrm{B}$, respectively, and the difference between the two groups was statistically significant $(p=0.012)$.

The mean duration of hospitalization was $8.60 \pm 5.30$ days in all patients. The mean durations of hospitalization found were $8.50 \pm 5.20$ days and $9.33 \pm 6.40$ days in group $A$ and group B, respectively. There was no significant difference between the groups in terms of the duration of hospitalization $(p=0.666)$. The mean length of stay in the ICU was $4.56 \pm 4.80$ days. The mean length of stay was found to be $4.40 \pm 4.85$ days in group A and $5.55 \pm 4.66$ days in group B. There was no statistically significant difference between the groups in terms of the length of stay in the ICU $(p=0.393)$.

When the patients' hemodynamic values at the time of admission were evaluated, tachycardia was found in 24 (45.3\%) patients and hypotension in $16(30.0 \%)$ of the patients in group A. In group B, seven (77.8\%) patients had tachycardia, and four (44.4\%) patients had hypotension at the time of first admission. $\mathrm{Hb}$ examined during the first admission was $<7 \mathrm{~g} / \mathrm{dL}$ in 17 of 53 patients (32.1\%) in group $\mathrm{A}$, and 5 (55.6\%) patients in group B. When patients were examined in terms of comorbidities; a history of CKD was found in 5 (9.4\%), CAD in 23 (43.4\%), and diabetes mellitus (DM) in 15 (28.3) patients in group A, while a history of CKD was found in 3 (33.3\%), CAD in 8 (88.8\%) and DM in $1(11.1 \%)$ patient in group B.

In the logistic regression analysis performed with several factors such as gender and the presence of tachycardia or hypotension at the time of admission, an initially measured $\mathrm{Hb}<7 \mathrm{~g} / \mathrm{dL}$, and the presence of $\mathrm{CKD}$, DM, and stable CAD; tachycardia found during the first admission; and presence of a history of accompanying CKD or CAD were determined as the independent risk factors in terms of elevated serum cTnl levels. Estimated relative risks [odds ratio (OR)] calculated for the presence of tachycardia, CKD, and stable CAD during the first admission were found

Table 1. Clinical, demographical and laboratory data of the groups

\begin{tabular}{|c|c|c|c|c|}
\hline & $\begin{array}{l}\text { Group A } \\
\text { CTnl }<0.06 \mathrm{mg} / \mathrm{L}(\mathrm{n}=53)(85.5 \%)\end{array}$ & $\begin{array}{l}\text { Group B } \\
\text { cTnl } \geq 0.06 \mathrm{mg} / \mathrm{L}(\mathrm{n}=9)(14.5 \%)\end{array}$ & $\begin{array}{l}\text { All patients } \\
(n=62)\end{array}$ & p \\
\hline Age & $70.15 \pm 13.7(25-92)$ & $79.6 \pm 6.0(73-87)$ & $71.5 \pm 13.3$ & 0.040 \\
\hline $\mathrm{Hb}(\mathrm{gr} / \mathrm{dL})$ & $8.6 \pm 2.7(3.7-15.5)$ & $7.3 \pm 2.9(5.1-14.7)$ & $8.36 \pm 2.7(3.7-15.5)$ & 0.072 \\
\hline WBC $\left(\times 10^{3}\right)$ & $13.6 \pm 9.6(2.3-67.3)$ & $11.9 \pm 3.7(4.6-16.0)$ & $13.3 \pm 8.9(2.3-67.3)$ & 0.96 \\
\hline Mean number of ES transfusions & $4.74 \pm 4.6$ & $7.44 \pm 7.7$ & $5.13 \pm 5.2$ & 0.350 \\
\hline Length of stay in ICU (days) & $4.40 \pm 4.85(0-26)$ & $5.56 \pm 4.66(1-15)$ & $4.56 \pm 4.80(0-26)$ & 0.393 \\
\hline Hospitalization (days) & $8.50 \pm 5.20(3-30)$ & $9.33 \pm 6.40(2-21)$ & $8.60 \pm 5.60(2-30)$ & 0.666 \\
\hline Glasgow-Blatchford score & $12.34 \pm 3.1(5-18)$ & $15.55 \pm 2.96(10-18)$ & $12.80 \pm 3.21(5-19)$ & 0.03 \\
\hline
\end{tabular}


as 11.2 [95\% confidence interval (Cl): 1.3-96.9], 11.5 (95\% Cl: 1.1-120.47), and 20.4 (95\% Cl: 1.75-238.6), respectively. The results of the logistic regression model examining the factors that contributed to elevation of cTnl are given in Table 2.

When the patients' 30-day mortality rates were evaluated, seven (11.3\%) patients died during daily follow-up due to various causes related to bleeding, whereas five (9.4\%) patients in group 1 died within 30 days from bleeding-related causes, this rate was $22.2 \%$ (two patients) in group 2. There was no statistically significant difference between the groups in terms of 30-day mortality rates $(p=0.262)$. Patients included in the study were divided into two groups according to mortality data. Patients who survived at the end of 30 days were assigned to group 1, and those who died within 30 days due to bleeding-related causes as group 2. Demographic and laboratory data of group 1 and group 2 are given in Table 3.

The mean serum CTnl level was found as $0.038 \pm 0.095 \mathrm{mg} / \mathrm{L}$ in group 1 and $0.077 \pm 0.11$ in group 2 . The difference between the two groups was not statistically significant $(p=0.067)$. When the groups were compared in terms of the length of stay in the ICU; the mean length of stay in the ICU was found to be $4.36 \pm 4.95$ days in group 1 and $6.14 \pm 3.34$ days in group 2. The mean length of stay in the ICU was longer in the patients in group 2, although the difference was not statistically significant $(p=0.058)$. However, the statistical analysis revealed that the patients in group 2 required more blood transfusions during their hospitalization. A mean of $4.51 \pm 4.5$ units erythrocyte suspension was transfused in group 1 , while this amount was $10.0 \pm 7.7$ units in group 2 , and the difference was statistically significant $(p=0.012)$.

The mean Rockall and Glasgow scores found were 5.76 \pm 1.69 and $12.80 \pm 3.21$ in all patients, respectively. In Pearson correlation analysis, it was found that the Rockall and Glasgow scores were correlated with serum cTnl levels, length of stay in the ICU, and the total number of erythrocyte suspensions given to patients during their hospitalization. Correlation analyses are summarized in Table 4.

In the ROC analysis, the optimal cut off values for serum cTnI concentrations and Rockall scores were found to be $0.025 \mathrm{mg} / \mathrm{L}$ and 6.5 , respectively. In the comparison of survival curves plotted according to the conditions of serum cTnl concentrations and Rockall scores being under or above the cut off values; there was a statistically significant difference in terms of survival for both serum cTnl concentrations (Mantel-Cox test: chi-square 6.426, $\mathrm{p}=0.011$ ) and Rockall scores (MantelCox test: chi-square 6.055, $p=0.014)$. Kaplan-Meier curves are seen in Figure 1, 2. According to Cox-regression analysis, the presence of CKD

Table 2. Factors contributing to elevated $\mathrm{CTnI}$ in the logistic regression analysis

\begin{tabular}{|c|c|c|c|c|}
\hline & $\begin{array}{l}\text { Group A } \\
\text { CTnl }<0.06 \mathrm{mg} / \mathrm{L}(\mathrm{n}=53) \\
(85.5 \%)\end{array}$ & $\begin{array}{l}\text { Group B } \\
\text { cTnl >0.06 mg/L (n=9) } \\
(14.5 \%)\end{array}$ & $\begin{array}{l}\text { All patients } \\
(n=62)\end{array}$ & OR $(95 \% \mathrm{Cl})$ \\
\hline Male (n, \%) & $39(73.6)$ & $4(44.4)$ & $43(69.4)$ & NS \\
\hline Tachycardia (\%) & $24(45.3)$ & $7(77.8)$ & $31(50)$ & $11.2(1.3-96.9)$ \\
\hline Hypotension (\%) & $16(30)$ & $4(44.4)$ & $20(32.3)$ & NS \\
\hline $\mathrm{Hb}<7 \mathrm{~g} / \mathrm{dL}(\%)$ & $17(32.1)$ & $5(55.6)$ & $22(35.5)$ & NS \\
\hline Cardiac disease presence (\%) & $23(43.4)$ & $8(88.1)$ & $31(50)$ & $20.4(1.75-238.6)$ \\
\hline Chronic kidney disease (\%) & $5(9.4)$ & $3(33.3)$ & $8(12.9)$ & $11.5(1.1-120.47)$ \\
\hline Diabetes mellitus presence (\%) & $15(28.3)$ & $1(11.1)$ & $16(25.8)$ & NS \\
\hline
\end{tabular}

Table 3. Clinical, demographic, and laboratory data of the groups

\begin{tabular}{|c|c|c|c|c|}
\hline & $\begin{array}{l}\text { Group1 } \\
\text { survived patients } \\
(n=55)(88.7 \%)\end{array}$ & $\begin{array}{l}\text { Group } 2 \\
\text { died patients } \\
(n=7)(11.3 \%)\end{array}$ & $\begin{array}{l}\text { All patients } \\
(n=62)\end{array}$ & p \\
\hline Age & $71.51 \pm 13.6(25-92)$ & $71.6 \pm 11.1(58-88)$ & $71.5 \pm 13.3(25-92)$ & 0.828 \\
\hline Male (\%) & $40(72.7)$ & $3(42.9)$ & $43(69.4)$ & 0.106 \\
\hline $\mathrm{Hb}(\mathrm{gr} / \mathrm{dL})$ & $8.5 \pm 2.8(3.7-15.5)$ & $6.9 \pm 1.9(4.0-10.1)$ & $8.4 \pm 2.7(3.7-15.5)$ & 0.133 \\
\hline WBC $\left(\times 10^{3}\right)$ & $13.6 \pm 9.6(2.3-67.3)$ & $11.9 \pm 3.7(4.6-16.0)$ & $13.3 \pm 8.9(2.3-67.3)$ & 0.151 \\
\hline BUN & $113.2 \pm 61.3(28.6-281)$ & $93.4 \pm 30(41.9-137.6)$ & $110.9 \pm 58.8(28.6-281)$ & 0.616 \\
\hline cTnl & $0.038 \pm 0.095(0.0-0.68)$ & $0.077 \pm 0.11(0.0-0.32)$ & $0.042 \pm 0.097(0.0-0.68)$ & 0.067 \\
\hline Rockall Score & $5.51 \pm 1.57(2-9)$ & $7.71 \pm 1.58(6-9)$ & $5.76 \pm 1.69(2-9)$ & 0.003 \\
\hline Glasgow Blatchfort score & $12.50 \pm 3.15(5-18)$ & $15.14 \pm 2.97(10-19)$ & $12.80 \pm 3.21(5-19)$ & 0.045 \\
\hline
\end{tabular}


Table 4. Correlation of $\mathrm{cTnl}$ with other factors

\begin{tabular}{|c|c|c|c|c|c|c|c|c|}
\hline & \multicolumn{2}{|c|}{ Rockall score } & \multicolumn{2}{|c|}{ Glasgow-Blatchford score } & \multicolumn{2}{|c|}{$\begin{array}{l}\text { Number of ES } \\
\text { transfusions }\end{array}$} & \multicolumn{2}{|c|}{$\begin{array}{l}\text { Length of stay in ICU } \\
\text { (days) }\end{array}$} \\
\hline & $\mathbf{p}$ & $\mathbf{P}$ & $p$ & $\mathbf{P}$ & $p$ & $\mathbf{P}$ & $p$ & $\mathbf{P}$ \\
\hline Rockall score & - & 1 & 0.001 & 0.400 & 0.002 & 0.381 & 0.006 & 0.347 \\
\hline Glasgow-Blacthford score & 0.001 & 0.400 & - & 1 & $<0.001$ & 0.520 & 0.003 & 0.368 \\
\hline
\end{tabular}

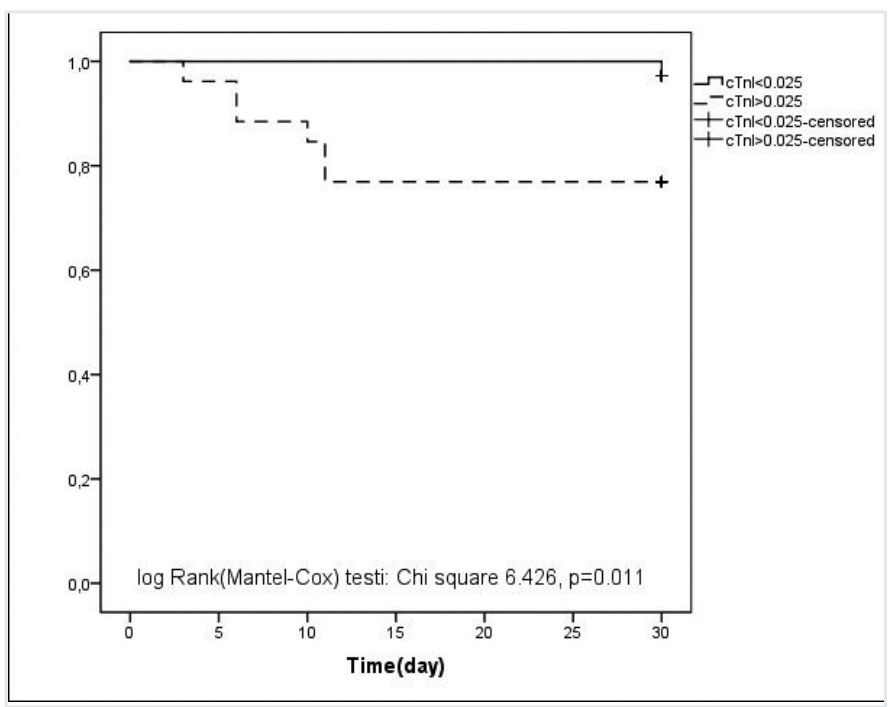

Figure 1. Correlation of $\mathrm{cTnl}$ levels with mortality cTnl: Cardiac troponin I

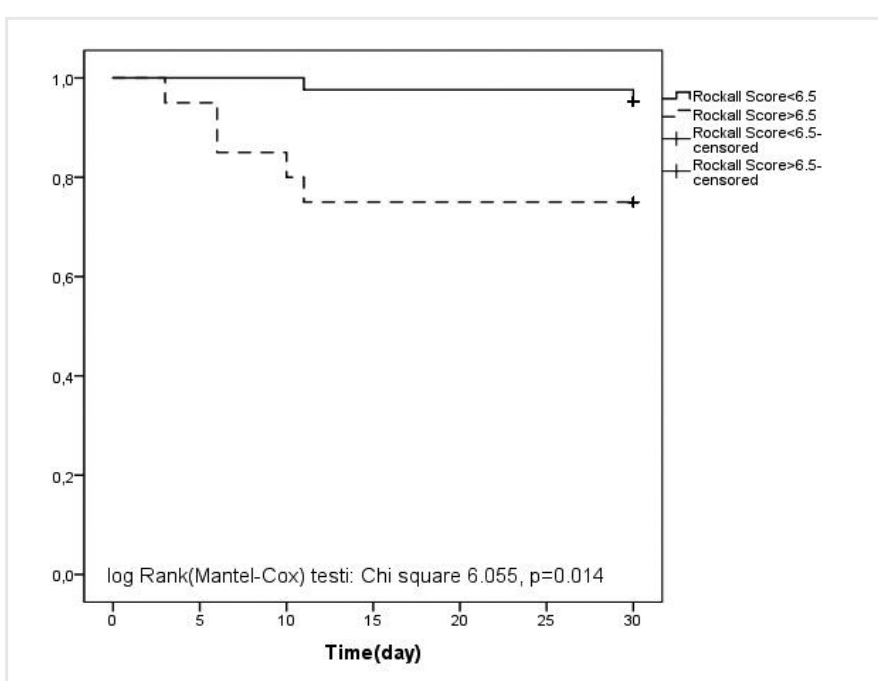

Figure 2. Correlation of Rockall score with mortality

as a comorbidity was found to be an independent risk factor associated with mortality in patients presenting with ANVUGIB (OR: 11.47, 95\% Cl: 1.35-97.63). On the other hand, the number of erythrocyte suspensions given to the patients during hospitalization, presence of hypotension or tachycardia at the first admission, gender, length of stay in the ICU, and presence of comorbidity (DM and CAD) alone were not mortality-related independent risk factors.

\section{Discussion}

Risk stratification, determination of low- and high-risk patients in an early period, and planning appropriate follow-up and treatment are crucial in patients with ANVUGIB $(16,17)$. At present, there is no ideal model used in the prediction of mortality in ANVUGIB. The Rockall score is one of the most commonly used scoring systems for this purpose. Although the effectivity of the Rockall score in the prediction of mortality and re-bleeding has been confirmed by many studies, its use is limited, especially in patients with unstable hemodynamics. Nonendoscopic factors such as age, shock, and comorbidity are involved in the calculation of the Rockall score, although the presence and characteristics of the lesion causing bleeding are important, and thus the calculation and use of the Rockall score is limited, especially in patients with unstable hemodynamics $(14,18-20)$. There are similar problems in the other various risk scoring systems, and there is still a need for an optimal marker to predict mortality and morbidity in ANVUGIB.

In the present study, serum cTnl levels were above the reference value that requires clinical follow-up (>0.06 mg/L) in $14.5 \%$ of all patients. All of these patients were investigated for the presence of acute coronary syndrome, which was then ruled out by clinical findings, electrocardiography, echocardiography, and clinical follow-up. In logistic regression analysis, CKD, CAD, and tachycardia were found as the independent risk factors affecting elevation of serum cTnI levels. In fact, there are various studies in the literature reporting elevated serum cTnI levels due to various reasons other than acute coronary syndrome. In a study by Alcalai et al. (7), serum cTnl levels were measured in all patients who presented to the hospital for various reasons within a 10-month period, and $53 \%$ of 635 patients with high serum level of cTnl were diagnosed with acute coronary syndrome, while elevated serum cTnI levels did not result from thrombotic causes in $41 \%$ of patients. In the same study, no explanation was for elevated serum cTnl levels in 6\% of the patients. According to that study, an important proportion of patients with elevated serum cTnl levels had no CAD. In the same study, patients with elevated serum cTnl levels that did not result from thrombotic causes were examined, and non-ischemic cardiac events such as myocarditis and arrhythmia were found in 11\%, sepsis in $8 \%$, pulmonary diseases in 7\%, cerebrovascular events in 5\%, surgical conditions (trauma, intensive gastrointestinal bleeding, intestinal obstruction etc) in 5\%, and renal failure in $2 \%$ of the patients, while $2 \%$ of the patients underwent cardiopulmonary resuscitation. Elevated serum cTnl levels are not easy 
to interpret in patients with CKD (21). Elevated serum cTnl levels in these patients may be related to subclinical myocardial damage, chronic inflammatory responses, and chronic volume load due to CKD. Many studies have shown that an elevated cTnl level was more significant and specific when patients with CKD were excluded. Data obtained from a smaller group of patients with renal failure showed that serum cTnl levels were associated with several complications, including increased rates of mortality $(21,22)$. Serum cTnl levels have also been reported to increase in patients with hypotension and sepsis $(10,23)$. It has been shown in coronary angiography or autopsy examinations that a large proportion of patients with sepsis and elevated serum cTnl levels had no CAD $(10,24)$. Although definitive cause of elevated $C T n l$ levels in sepsis is not clear, several factors, such as cytotoxic endotoxins, inflammatory mediators, septic microemboli, vasoactive drugs used in the treatment, and accompanying hypotension, are thought to be responsible for this elevation $(25,26)$. Studies have shown that elevated serum cTnl levels were associated with the severity of sepsis, multiple organ failure, and mortality, and that increased cTnl levels were especially observed in streptococcic sepsis and gram-negative sepsis (27).

Today, serum cTnl levels are recognized as one of the independent predictors of risk in acute coronary syndrome (3). In addition, there are studies reporting that elevated serum cTnl levels occurring for various reasons other than acute coronary syndrome have short- and long-term prognostic value in various diseases $(10,21,24)$. Perioperative cTnl levels have been shown to be significant in the determination of cardiac risk after open cardiac surgery (28). In studies including asymptomatic dialysis patients with CKD and excluding patients with angina pectoris and acute coronary syndrome, cTnl levels were found to be high; the same studies also showed that in addition to cardiac death, noncardiac death was also increased in patients with high serum cTnl levels (29). It has been shown that serum cTnl levels were increased, in the acute exacerbation period in patients with chronic obstructive pulmonary disease (COPD), length of stay in ICU and the need for ventilation were increased in patients with high serum cTnl levels, and it has been proposed that cTnl levels can be used in determination of high-risk groups in terms of acute exacerbation attacks in COPD patients, but an association between serum cTnl levels and mortality could not be demonstrated (30). On the other hand, there are studies reporting that an elevated serum cTnl level was correlated with short- and long-term mortality and morbidity in patients who had an ischemic stroke $(31,32)$. An elevated serum cTnl level has been shown to be an independent predictor of mortality in patients hospitalized in the ICU due to pneumonia who had no acute coronary syndrome (33).

Based on the results of this study, we believe that elevated serum cTn1 levels in patients with ANVUGIB without acute coronary syndrome might result from relative cardiac ischemia caused by bleeding and volume loss, tachycardia, and hemodynamic instability. In fact, one of the noteworthy points of the study was that patients with elevated serum cTn1 levels were more hemodynamically unstable. It was found that $\mathrm{Hb}$ values at admission were lower, hypotension and tachycardia during the first admission were more common, length of stay in the ICU was longer, the need for transfusion was more common, and the 30-day mortality rate was higher in patients with elevated serum CTn1 levels. However, although the numerical difference was significant for most of these parameters, the difference was not statistically significant due to the small number of patients. Therefore, we plan to confirm these results with a prospective study to be conducted with a sufficient number of cases.

Another remarkable point of this study was that even a serum cTnl level above the cut-off point that was determined as much lower than the level requiring clinical follow-up $(0.025 \mathrm{mg} / \mathrm{L})$ affected mortality. Given that there is still no optimal method to determine risk in the management of patients with ANVUGIB, the serum cTnl level could be used as a non-invasive and inexpensive biomarker for risk stratification in patients with ANVUGIB.

\section{Study Limitation}

The most important limitation of this study was its retrospective design and relatively small number of patients. Due to the small number of patients, despite significant numerical differences between the groups in terms of various parameters, these differences did not reach statistical significance.

\section{Conclusion}

Serum cTnl levels may be elevated in patients with ANVUGIB, even in the absence of acute coronary syndrome, and high serum cTnl levels are associated with mortality in these patients. Therefore, we believe that investigation of serum cTnl levels during initial admission of patients presenting with ANVUGIB, even if they have no acute coronary syndrome, will be found useful among the other risk stratification methods and scoring systems in terms of the determination of high-risk patients.

\section{Ethics}

Ethics Committee Approval: The study was approved by Necmettin Erbakan University, Meram Faculty of Medicine Ethics Committee (approval number: 2017/811, date: 24.02.2017).

Informed Consent: All participants provided written consent for participation in the study.

Peer-review: Externally peer-reviewed.

Authorship Contributions: Surgical and Medical Practices - R.D., M.B., M.K., H.A., M.A.; Concept - R.D., R.Y., A.K., H.A., M.A.; Design - R.D., M.K., A.K., H.P., A.D., M.A.; Data Collection or Processing - M.B., R.Y., M.K., Y.K.; Analysis or Interpretation - R.D., A.K., Y.K., H.P.; Literature Search - R.D., M.B., Y.K., H.A., A.D.; Writing - R.D., M.A.

Conflict of Interest: No conflict of interest was declared by the authors

Financial Disclosure: The authors declared that this study received no financial support.

\section{References}

1. Sey MSL, Mohammed SB, Brahmania M, Singh S, Kahan BC, Jairath V. Comparative outcomes in patients with ulcer-vs non-ulcer-related acute upper gastrointestinal bleeding in the United Kingdom: a nationwide cohort of 4474 patients. Aliment Pharmacol Ther 2019; 49: 537-45. 
2. Jairath $\mathrm{V}$, Martel M, Logan RF, Barkun AN. Why do mortality rates for nonvariceal upper gastrointestinal bleeding differ around the world? A systematic review of cohort studies. Can J Gastroenterol 2012; 26: 537-43.

3. Thygesen K, Alpert JS, Jaffe AS, Chaitman BR, Bax JJ, Morrow DA, et al. Fourth Universal Definition of Myocardial Infarction. J Am Coll Cardiol 2018; 72: 2231-64.

4. Mair J, Wagner I, Puschendorf B, Mair P, Lechleitner P, Dienstl F, et al. Cardiac troponin I to diagnose myocardial injury. Lancet 1993; 341: 838-9.

5. Korff S, Katus HA, Giannitsis E. Differential diagnosis of elevated troponins. Heart 2006; 92: 987-93.

6. Farber AJ, Suarez K, Slicker K, Patel CD, Pope B, et al. Frequency of Troponin Testing in Inpatient Versus Outpatient Settings. Am J Cardiol 2017; 119: 11535.

7. Alcalai R, Planer D, Culhaoglu A, Osman A, Pollak A, Lotan C. Acute coronary syndrome vs nonspecific troponin elevation: clinical predictors and survival analysis. Arch Intern Med 2007; 167: 276-81.

8. Widmer RJ, Wilson G, Haneke T, Lee M, Fan J, Davis A, et al. Inpatient Mortality and 30-Day Readmission Rates Associated with Troponin Testing in Patients without Acute Myocardial Infarction. Clin Med Res 2020; 18: 82-8.

9. Iser DM, Thompson AJ, Sia KK, Yeomans ND, Chen RY. Prospective study of cardiac troponin I release in patients with upper gastrointestinal bleeding. J Gastroenterol Hepatol 2008; 23: 938-42.

10. Abdalla M, Sohal S, Al-Azzam B, Mohamed W. Effect of Troponin I Elevation on Duration of Mechanical Ventilation and Length of Intensive Care Unit Stay in Patients With Sepsis. J Clin Med Res 2019; 11: 127-32.

11. Ammann P, Maggiorini M, Bertel O, Haenseler E, Joller-Jemelka HI, Oechslin $\mathrm{E}$, et al. Troponin as a risk factor for mortality in critically ill patients without acute coronary syndromes. J Am Coll Cardiol 2003; 41: 2004-9.

12. Wang N, Li T, Du Q. Risk factors of upper gastrointestinal hemorrhage with acute coronary syndrome. Am J Emerg Med 2019; 37: 615-9.

13. Blatchford O, Murray WR, Blatchford M. A risk score to predict need for treatment for upper-gastrointestinal haemorrhage. Lancet 2000; 356: 131821.

14. Rockall T, Devlin H, Logan R, Northfield T. Selection of patients for early discharge or outpatient care after acute upper gastrointestinal haemorrhage. Lancet 1996; 347: 1138-40.

15. Forrest JH, Finlayson ND, Shearman DJ. Endoscopy in gastrointestinal bleeding. Lancet 1974; 304: 394-7.

16. Gralnek IM, Dumonceau JM, Kuipers EJ, Lanas A, Sanders DS, Kurien M, et al. Diagnosis and management of nonvariceal upper gastrointestinal hemorrhage: European Society of Gastrointestinal Endoscopy (ESGE) Guideline. Endoscopy 2015; 47: 1-46.

17. Laine L, Jensen DM. Management of patients with ulcer bleeding. Am J Gastroenterol 2012; 107: 345-60.

18. Das A, Wong RC. Prediction of outcome of acute GI hemorrhage: a review of risk scores and predictive models. Gastrointest Endosc 2004; 60: 85-93.
19. Marmo R, Koch M, Cipolletta L, Capurso L, Pera A, Bianco MA, et al. Predictive factors of mortality from nonvariceal upper gastrointestinal hemorrhage: a multicenter study. Am J Gastroenterol 2008; 103: 1639-47.

20. Laursen SB, Dalton HR, Murray IA, Michell N, Johnston MR, Schultz M, et al. Performance of new thresholds of the Glasgow Blatchford score in managing patients with upper gastrointestinal bleeding. Clin Gastroenterol Hepatol 2015; 13: 115-21.

21. Maresca B, Manzione A, Moioli A, Salerno G, Cardelli P, Punzo G, et al. Prognostic value of high-sensitive cardiac troponin I in asymptomatic chronic hemodialysis patients. J Nephrol 2020; 33: 129-36.

22. Artunc F, Haag S, Friedrich B, Mueller C, Häring HU, Peter A. Performance of a novel high sensitivity cardiac troponin I assay in asymptomatic hemodialysis patients - evidence for sex-specific differences. Clin Chem Lab Med 2019; 57: $1261-70$.

23. Arlati S, Brenna S, Prencipe L, Marocchi, A, Casella GP, Lanzani M, et al. Myocardial necrosis in ICU patients with acute non-cardiac disease: a prospective study. Intensive Care Med 2000; 26: 31-7.

24. Jendoubi A, Jerbi S, Maamar E, Abbess A, Samoud Z, Kanzari L, at al. Prognostic Value of High-sensitivity Troponin I in Patients with Septic Shock: A Prospective Observational Study. Indian J Crit Care Med 2019; 23: 320-5.

25. Skeik N, Patel DC. A review of troponins in ischemic heart disease and other conditions. Int J Angiol 2007; 16: 53-8.

26. Dauhan AC, Lubis AD, Mutiara E, Lubis M. Correlation of Troponin Level (Troponin T, Troponin I) With PELOD-2 Score in Sepsis as a Predictive Factor of Mortality. Open Access Maced J Med Sci 2019; 7: 4072-7.

27. Klein Gunnewiek JMT, van de Leur JJJPM. Elevated troponin T concentrations in critically ill patients. Intensive Care Med 2003; 29: 2317-22.

28. Hazar A, Cihan HB, Gülcan Ö, Çı̆̆lı A, Özyalın F, Türköz R. Perioperatif miyokardiyal hasar tespitinde biyokimyasal belirleyicilerin rolü. Turgut Özal Tıp Merkezi Dergisi 2002; 9: 95-103.

29. Alam A, Palumbo A, Mucsi I, Barré PE, Sniderman AD. Elevated troponin I levels but not low grade chronic inflammation is associated with cardiacspecific mortality in stable hemodialysis patients. BMC Nephrol 2013; 14 : 247-54.

30. Noorain S. Prognostic value of cardiac troponin I during acute exacerbation of chronic obstructive pulmonary disease: A prospective study. Lung India 2016; 33: 53-7.

31. Scheitz JF, Nolte CH, Laufs U, Endres M. Application and interpretation of high-sensitivity cardiac troponin assays in patients with acute ischemic stroke. Stroke 2015; 46: 1132-40.

32. Thålin C, Rudberg AS, Johansson F, Jonsson F, Laska AC, Nygren AT, et al. Elevated troponin levels in acute stroke patients predict long-term mortality. J Stroke Cerebrovasc Dis 2015; 24: 2390-6.

33. Lee YJ, Lee H, Park JS, Kim SJ, Cho YJ, Yoon HI, et al. Cardiac troponin I as a prognostic factor in critically ill pneumonia patients in the absence of acute coronary syndrome. J Crit Care 2015; 30: 390-4. 